\title{
Kandungan Gizi dan Karakterisasi Senyawa Bioaktif Lintah Laut (Discodoris sp.) \\ Nutritional Content and Characterization Bioactive Compounds of Sea Sluge (Discodoris sp.)
}

\author{
Hafiluddin $^{1)}$, Nurjanah ${ }^{2)}$ dan Tati Nurhayati ${ }^{3)}$
}

(1) Jurusan Ilmu Kelautan, Universitas Trunojoyo

(2), (3) Jurusan Teknologi Hasil Perairan, Universitas Trunojoyo

Jl. Raya Telang, Kecamatan Kamal

Kabupaten Madura, 16912 Telp. 031 - 3011146, Fax. 031 - 3011506

\begin{abstract}
One of the commodities produced from the ocean that have a bioactive compounds is a sea slug (Discodoris sp.). That is very interesting to study mainly deals with the nature of both chemical and biochemical characteristics and their use for the field of food and health. The aims of this research was to determine the nutrient content of sea slug, determaine chemical content and determine antioxidant activity. The experiment was conducted with several stages: sample preparation, analysis of nutrient content, extraction bioactive compound, analysis of chemical content and antioxidant activity. Sea slug from the island of Madura Pamekasan potential as a source of protein, fat, and minerals. Sea slug has esensial amino acids amount to $5.57 \%$ was dominated by leucin of $1.42 \%$. Nonesensial amino acids amount to $6.54 \%$ wich was dominated by glutamic acid $2.19 \%$. Saturated fatty acids amounted to $27.53 \%$ of sea slug was dominated by palmitic (C16: 0$)$ which was $13.36 \%$. Unsaturated fatty acids amounted to $34.66 \%$, which was dominated by the essential fatty acids linolenic (C18: 3 , n-3) $20.91 \%$. The highest yield of the crude extract was ethanol and contained alkaloid compounds, steroids, phenols, carbohydrates and reducing sugar compound. The meat of sea slug with ethanol solvent has an $\mathrm{IC}_{50}$ best antioxidant activity at $441,12 \mathrm{ppm}$.
\end{abstract}

Keywords : antioxidant, nutrition, sea sluge (Discodoris sp.)

\section{Pendahuluan}

Kondisi alam dan iklim Indonesia yang tidak fluktuatif membuat laut di Indonesia memiliki potensi sumberdaya dengan keanekaragaman hayati yang sangat besar. Sumberdaya laut tersebut belum terdayagunakan secara optimal. Pemanfaatan sumberdaya laut selain sebagai sumber pangan, juga berpotensi sebagai sumber senyawa bioaktif yang lebih bernilai ekonomis.

Salah satu komoditi yang dihasilkan dari laut dan mempunyai senyawa bioaktif adalah lintah laut (Discodoris sp). Senyawa bioaktif lintah laut sangat menarik untuk diteliti terutama berkaitan dengan sifat karakteristik kimia maupun biokimianya serta pemanfaatannya untuk bidang pangan dan kesehatan. Menurut pengalaman empiris, lintah laut telah lama digunakan oleh masyarakat pantai di daerah Pamekasan Madura yang dikenal dengan nama lokal "kok-okok" karena lintah laut tubuhnya bisa memanjang dan mengkerut apabila disentuh. Lintah laut digunakan sebagai bahan pangan dan obat untuk menyembuhkan penyakit borok payudara bagi orang hamil dan menyusui. Lintah laut juga digunakan sebagai jamu untuk menyembuhkan penyakit punggung dan meningkatkan stamina.
Beberapa penelitian tentang lintah laut telah dilakukan yaitu isolasi senyawa steroid dari lintah laut dan ditemukan 7 jenis senyawa metabolit yang salah satu diantaranya adalah senyawa androgen (Ibrahim 2001). Peneliti lain mengungkapkan bahwa lintah laut mengandung asam lemak jenuh dan tidak jenuh serta sterol pada fraksi nonpolar (Witjaksono 2005). Hasil uji fitokimia dari ekstrak metanol lintah laut diperoleh kelompok alkaloid, steroid, asam amino, saponin dan fenol yang berperan sebagai antioksidan serta diperoleh rendemen yang terbesar yaitu 5,119\% dengan aktivitas antioksidan 89,44\% dibandingkan dengan pelarut yang lain (Nurjanah et al. 2010). Pemanfaatan lintah laut sebagai minuman fungsional dengan fungsi sebagai antioksidan telah diteliti oleh Nai'u (2010).

Penelitian yang komphrehensif tentang kandungan gizi dan komponen bioaktif dari lintah laut jenis Discodoris sp. ini masih sangat kurang, khasiat dan manfaatnya secara empiris perlu dibuktikan, sehingga diperlukan penelitian yang lebih lengkap untuk mengekstraksi, mengkarakterisasi dan mengidentifikasi senyawa bioaktif dari lintah laut. 


\section{Metodologi Penelitian}

Tempat dan Waktu

Penelitian ini dilaksanakan pada Bulan Juni sampai November 2010, bertempat di Laboratorium bagian Preparasi Bahan Baku Hasil Perairan, Laboratorium Biokimia Hasil Perikanan, Laboratorium Mikrobiologi Hasil Perikanan, Laboratorium Bioteknologi Hasil Perairan II, Departemen Hasil Perairan, Fakultas Perikanan dan Ilmu Kelautan IPB. Balai Besar Penelitian dan Pengembangan Pascapanen Pertanian Cimanggu Bogor.

Bahan dan Alat

Bahan yang digunakan pada penelitian ini berupa lintah laut. Bahan ekstraksi: kloroform, etil asetat dan etanol. Bahan untuk analisis proksimat, asam amino, asam lemak, mineral dan logam berat. Bahan untuk uji antioksidan: DPPH (1,1-difenil-2pikrilhidrazil) dan BHT (Butylated Hydroxytoluena). Alat yang digunakan pada penelitian ini adalah alat tulis, alat-alat gelas, alat ekstraksi dan uji kimia antara lain: rotari evaporator Buchi Rotavapor R-205, spektrofotometer UV-VIS Hitachi U-2800, AAS Shimazu-7000, HPLC Varian 940-LC.

\section{Preparasi Sampel}

Penelitian dilakukan dari pengambilan dan preparasi sampel. Lintah laut diambil dari pantai di daerah Pamekasan Madura. Setelah bersih lintah laut dikeluarkan isi perutnya dengan cara membelahnya secara melintang dari oral menuju aboral. dikeringkan sekitar 3-4 hari dengan sinar matahari dan dihaluskan dengan mortal atau blender. Analisis kandungan gisi pada lintah meliputi analisa proksimat (AOAC 2005), asam amino (AACC 1983), asam lemak (AACC 1994) serta analisis kandungan mineral dan logam berat (SNI 01-28961998).

\section{Ekstraksi Lintah Laut}

Ekstraksi dilakukan dengan metode ekstraksi bertingkat, menggunakan perbedaan kepolaran pelarut yang mengacu pada metode Sherif et al. 2008. Sebanyak 50 gram bubuk lintah laut dimasukkan ke dalam gelas erlenmeyer dan ditambahkan dengan $100 \mathrm{ml}$ pelarut kloroform. Campuran dikocok dengan shaker dan dibiarkan hingga terjadi pemisahan, fraksi terlarut dalam kloroform dipisahkan dan dimasukkan ke dalam labu. Ekstraksi menggunakan pelarut kloroform ini dilakukan sampai larutan berwarna jernih. Fraksi ini merupakan fraksi dengan tingkat kepolaran rendah. Kemudian dilanjutkan dengan pelarut yang lain yaitu etil asetat dan etanol. Larutan hasil ekstraksi bertingkat dikeringkan dengan evaporator pada suhu kamar $40{ }^{\circ} \mathrm{C}$. Fraksi-fraksi yang diperoleh kemudian dikeringkan dengan freezdryer. Analisis yang dilakukan pada ekstrak kasar yaitu uji fitokimia (Departemen Kesehatan RI 1995) dan aktivitas antioksidan (Blois 1958 dalam Hanani et al. 2005).

\section{Hasil dan Pembahasan}

Rendemen Preparasi Lintah Laut

Hasil pengukuran rendemen lintah laut pada Tabel 1 menunjukkan bahwa daging segar setelah preparasi sebesar 50,00\% dan bagian jeroan sebesar $16,67 \%$ serta bagian lain berupa lendir, darah dan air sebesar 33,33\%. Setelah dikeringkan rendemen berubah menjadi semakin kecil yang disebabkan banyaknya kandungan air yang menguap. Jumlah rendemen pada bagian daging setelah pengeringan menjadi 13,33\% dan pada bagian jeroan sebesar 4,67\%. Penurunan rendemen lintah laut disebabkan penguapan kandungan air dalam bahan dengan adanya energi panas matahari.

Tabel 1. Rendemen lintah laut setelah preparasi

\begin{tabular}{lcc}
\hline \multicolumn{1}{c}{ Keterangan } & Berat Segar & Berat Kering \\
\hline Lintah laut utuh & $3000 \mathrm{~g}$ & \\
Daging lintah laut & $50,00 \%$ & $13,33 \%$ \\
Jeroan lintah laut & $16,67 \%$ & $4,67 \%$ \\
Sisa & $33,33 \%$ & \\
\hline
\end{tabular}

Kandungan Gizi Lintah Laut

Lintah laut (Discodoris sp.) yang berasal dari perairan pantai Kabupaten Pamekasan Madura memiliki kandungan proksimat protein tertinggi pada bahan segar yaitu $13,60 \pm 0,16 \%$ pada jeroan, sedangkan pada bahan kering protein tertinggi diperoleh pada bagian daging yaitu $45,13 \pm 0,29 \%$. Kadar lemak tertinggi pada bahan segar diperoleh dari bagian daging yaitu $0,44 \pm 0,06 \%$, sedangkan pada bagian kering kadar lemak tertinggi diperoleh dari bagian jeroan yaitu $7,10 \pm 0,44 \%$. Hasil analisis proksimat lebih lengkap dapat dilihat pada Tabel 2. Hasil ini berbeda dengan yang dilaporkan oleh Witjaksono (2005), Andriyanti (2009) dan Nurjanah (2010). Perbedaan kandungan proksimat pada lintah laut tersebut disebabkan karena perbedaan asal sampel yang digunakan, jenis dan ukuran, umur dan lingkungan.

Asam amino essensial yang terdapat pada daging lintah laut yaitu lisin, leusin, isoleusin, 
treonin, methionin, valin, phenilalanin, dan histidin. Asam amino non essensial pada lintah laut yaitu asam aspartat, asam glutamat, glisin, serin, alanin polin, triosin, arginin, dan sistein (Tabel 3). Kandungan asama amino paling besar yaitu asam glutamat sebesar 2,19\% pada daging dan 2,14\% pada jeroan. Asam glutamat merupakan jenis asam amino glukonik yang diduga memberikan rasa manis dan gurih pada daging lintah laut, sehingga lintah laut ini bisa dimakan dan disukai oleh sebagian masyarakat pesisir seperti yang sudah dilakukan oleh masyarakat sekitar pantai daerah Pamekasan Madura.

Tabel 2. Hasil analisis proksimat lintah laut (Discodoris sp.)

\begin{tabular}{|c|c|c|c|c|c|c|c|}
\hline \multirow{2}{*}{ Keterangan } & \multicolumn{2}{|c|}{ Segar } & \multicolumn{2}{|c|}{ Kering } & \multirow{2}{*}{$\begin{array}{c}\text { Discodoris } \\
\text { baholensis } \\
\text { (a) }\end{array}$} & \multirow{2}{*}{$\begin{array}{l}\text { Discodoris } \\
\text { sp. (b) }\end{array}$} & \multirow{2}{*}{$\begin{array}{c}\text { Discodoris } \\
\text { sp. (c) }\end{array}$} \\
\hline & Daging & Jeroan & Daging & Jeroan & & & \\
\hline $\begin{array}{c}\text { Kadar air } \\
(\%)\end{array}$ & $83,00 \pm 1,25$ & $77,93 \pm 0,27$ & $11,17 \pm 1,49$ & $9,22 \pm 1,11$ & 19,36 & 10,45 & 15,25 \\
\hline $\begin{array}{c}\text { Kadar abu } \\
(\%)\end{array}$ & $1,87 \pm 0,20$ & $2,92 \pm 0,32$ & $17,96 \pm 0,25$ & $26,86 \pm 0,64$ & 10,69 & 11,97 & 11,74 \\
\hline $\begin{array}{c}\text { Kadar } \\
\text { protein }(\%)\end{array}$ & $12,31 \pm 0,86$ & $13,60 \pm 0,16$ & $45,13 \pm 0,29$ & $37,57 \pm 1,21$ & 59,79 & 59,11 & 49,60 \\
\hline $\begin{array}{c}\text { Kadar lemak } \\
(\%)\end{array}$ & $0,44 \pm 0,06$ & $0,44 \pm 0,04$ & $2,67 \pm 0,14$ & $7,10 \pm 0,44$ & 5,84 & 1,41 & 4,58 \\
\hline $\begin{array}{c}\text { Kadar } \\
\text { karbohidrat } \\
(\%)\end{array}$ & $2,38 \pm 1,87$ & $5,12 \pm 0,62$ & $23,07 \pm 1,83$ & $19,26 \pm 0,86$ & 4,42 & 17,08 & 18,83 \\
\hline
\end{tabular}

Sumber: (a); Witjaksono (2005)

(b) ; Andriyanti (2009)

(c); Nurjanah (2010)

Lintah laut (Discodoris sp.) memiki asam lemak jenuh (saturated fatty acid) yaitu laurat (C12:0) 4,59\%, miristat (C14:0) 1,11\%, palmitat (C16:0) 13,37\%. Lintah laut juga memiliki asam lemak tidak jenuh (unsaturated fatty acid) yang terdiri dari asam lemak tidak jenuh tunggal (monounsatuted fatty acid) yaitu oleat (C18:1,n-9) $8,13 \%$ dan asam lemak tidak jenuh jamak (polyunsaturated fatty acid) yaitu linoleat (C18:2,n-
6) $5,63 \%$ dan linolenat (C18:3,n-3) 20,91\%. Komposisi asam lemak lintah laut disajikan pada Tabel 4. Komposisi dari asam lemak pada lintah laut didominasi oleh asam lemak tidak jenuh jamak yaitu linolenat yang terletak pada bagian daging lintah laut, asam lemak oleat dan linoleat. Asam lemak tidak jenuh tersebut yang diduga berperan sebagai antioksidan dalam lintah laut.

Tabel 3. Komposisi asam amino pada lintah alut (Discodoris sp.)

\begin{tabular}{|c|c|c|c|c|c|c|c|}
\hline \multirow{2}{*}{ No. } & \multirow{2}{*}{ Jenis Asam Amino } & \multicolumn{2}{|c|}{ Hasil (\%) } & \multirow{2}{*}{ No. } & \multirow{2}{*}{ Jenis Asam Amino } & \multicolumn{2}{|c|}{ Hasil (\%) } \\
\hline & & Daging & Jeroan & & & Daging & Jeroan \\
\hline & Asam amino esensial & 5,57 & 5,69 & & Asam amino non esensial & 6,54 & 6,76 \\
\hline 1 & Leusin & 1,42 & 1,67 & 1 & Asam Glutamat & 2,19 & 2,14 \\
\hline 2 & Lisin & 1,40 & 1,22 & 2 & Prolin & 1,18 & 1,19 \\
\hline 3 & Valin & 0,81 & 0,83 & 3 & Asam Aspartat & 0,91 & 0,96 \\
\hline 4 & Treonin & 0,52 & 0,57 & 4 & Serin & 0,55 & 0,61 \\
\hline 5 & Isoleusin & 0,43 & 0,34 & 5 & Triosin & 0,50 & 0,48 \\
\hline 6 & Phenilalanin & 0,36 & 0,46 & 6 & Arginin & 0,46 & 0,52 \\
\hline 7 & Histidin & 0,35 & 0,35 & 7 & Alanin & 0,39 & 0,44 \\
\hline \multirow[t]{2}{*}{8} & Methionin & 0,28 & 0,25 & 8 & Glisin & 0,22 & 0,26 \\
\hline & & & & 9 & Sistein & 0,14 & 0,16 \\
\hline
\end{tabular}


Kandungan mineral tertinggi pada lintah laut yaitu pada jeroan meliputi kalium 206,05 ppm, kalsium 187,66 ppm, magnesium 112,4 ppm dan beberapa mineral mikro yaitu $\mathrm{Zn}, \mathrm{Fe}$, dan Mn (Tabel 5). Logam berat $\mathrm{Pb}$ yaitu $0,73 \mathrm{ppm}$ (daging) dan 0,59 ppm (jeroan) $\mathrm{Hg}, \mathrm{Cd}$ dan As tidak terdeteksi pada lintah laut asal perairan Madura tersebut. Logam berat ini masih berada di bawah batas maksium logam cemaran dalam ikan dan produk perikanan termasuk jenis moluska yaitu kadmium 1,0 $\mathrm{mg} / \mathrm{kg}$, merkuri $1,0 \mathrm{mg} / \mathrm{kg}$, timbal $1,5 \mathrm{mg} / \mathrm{kg}$, dan arsen 1,0 mg/kg (SNI 7387-2009).

Tabel 4. Komposisi asam lemak lintah laut

\begin{tabular}{llrr}
\multicolumn{3}{c}{ (Discodiris sp.) } & \\
\hline \multirow{2}{*}{ No. } & \multirow{2}{*}{ Jenis asam lemak } & \multicolumn{2}{c}{ Hasil (\%) } \\
\cline { 3 - 4 } & & Daging & Jeroan \\
\hline \multirow{2}{*}{ Asam lemak jenuh } & 27,53 & 29,82 \\
\hline 1 & Palmitat (C16:0) & 13,36 & 16,74 \\
2 & Stearat (C16:0) & 8,48 & 6,87 \\
3 & Laurat (C16:0) & 4,58 & 3,53 \\
4 & Miristat (C16:0) & 1,11 & 2,68 \\
\hline & Asam lemak tidak jenuh & 34,66 & 17,95 \\
\hline \multirow{2}{*}{1} & Oleat & 8,12 & 7,63 \\
& Essential fatty acid (EFA) : & & \\
2 & Linolenat & 20,91 & 4,22 \\
3 & Linoleat & 5,63 & 6,10 \\
\hline
\end{tabular}

Tabel 5. Hasil analisi kandungan mineral lintah laut (Discodiris sp.)

\begin{tabular}{llll}
\hline \multirow{2}{*}{ No. } & Jenis mineral & \multicolumn{2}{c}{ Hasil (ppm) } \\
\cline { 3 - 4 } & & Daging & Jeroan \\
\hline \multicolumn{3}{l}{ Makro mineral } & \\
\hline 1 & $\mathrm{Ka}$ & 197,86 & 206,05 \\
2 & $\mathrm{Ca}$ & 179,98 & 187,66 \\
3 & $\mathrm{Mg}$ & 110,95 & 112,40 \\
& & & \\
\hline & Mikro mineral & & \\
\hline 1 & $\mathrm{Zn}$ & 7,52 & 4,35 \\
2 & $\mathrm{Fe}$ & 6,99 & 5,17 \\
3 & $\mathrm{Mn}$ & 6,93 & 7,25 \\
& & & \\
\hline
\end{tabular}

Rendemen Ekstraksi Lintah Laut

Rendemen merupakan perbandingan berat ekstrak yang diperoleh dengan bobot awal sampel yang digunakan. Tabel 6 menunjukkan bahwa ekstrak etanol memiliki rendemen yang tertinggi yaitu 5,08\% (daging) dan 6,97\% (jeroan). Tingginya rendemen pada bagian jeroan disebabkan oleh perbedaan ukuran partikel dan kemudahan sel untuk pecah dimana pada bagian jeroan lintah memiliki sifat mudah dihancurkan dibandingkan pada bagian daging lintah laut. Semakin kecil ukuran partikel maka semakin luas terjadinya kontak dengan pelarut.

Tabel 6. Rendemen ekstrak lintah laut

\begin{tabular}{cccc}
\hline \multirow{2}{*}{ Keterangan } & \multicolumn{3}{c}{ Berat ekstrak } \\
\cline { 2 - 4 } & Kloroform & Etil asetat & Etanol \\
\hline $\begin{array}{c}\text { Daging } \\
\text { lintah laut }\end{array}$ & $4,53 \%$ & $1,14 \%$ & $5,08 \%$ \\
$\begin{array}{c}\text { Jeroan } \\
\text { lintah laut }\end{array}$ & $3,09 \%$ & $0,86 \%$ & $6,97 \%$ \\
\hline
\end{tabular}

Kandungan Senyawa Kimia Ekstrak Lintah Laut Bioaktivitas lintah laut sangat dipengaruhi oleh kandungan senyawa kimia yang terdapat di dalam bahan, perbedaan kandungan senyawa kimia menentukan aktivitas biologis dari lintah laut. Hasil pemeriksaan komponen bioaktif yang terdapat dalam ekstrak kasar lintah laut disajikan pada Tabel 7 . Komponen bioaktif pada lintah laut yaitu alkaloid, steroid, dan karbohidrat, fenol, saponin, molisch dan ninhidrin. Tabel 7 menunjukkan bahwa pada ekstrak etanol daging memiliki komponen kimia paling lengkap dibandingkan yang lain. Ekstraksi dengan pelarut etanol dapat memisahkan senyawa fenolik, steroid, terpenoid, alkaloid dan glikosida (Hougton dan Raman 1998).

Tabel 7. Hasil uji fitokimia ekstrak kasar lintah laut (Discodiris sp.)

\begin{tabular}{ll}
\hline Sampel & Komponen kimia \\
\hline $\begin{array}{l}\text { Kloroform } \\
\text { daging }\end{array}$ & Alkaloid, steroid, molisch, ninhidrin \\
$\begin{array}{l}\text { Kloroform } \\
\text { jeroan }\end{array}$ & Alkaloid, fenol, molisch \\
$\begin{array}{l}\text { Etil asetat } \\
\text { daging }\end{array}$ & Alkaloid, molisch \\
$\begin{array}{l}\text { Etil asetat } \\
\text { jeroan }\end{array}$ & Alkaloid, steroid, molisch, ninhidrin \\
Etanol & Alkaloid, steroid, saponin, fenol, \\
daging & molisch, ninhidrin \\
Etranol & Alkaloid, molisch, benedict \\
jeroan & \\
\hline
\end{tabular}


Aktivitas Antioksidan Ekstrak Kasar Lintah Laut

Antioksidan merupakan senyawa yang dapat menunda, menghambat dan mencegah oksidasi lemak atau molekul lainnya dengan cara mencegah terbentuknya radikal bebas (Rohman et al. 2006). Keberadaan senyawa antioksidan dalam suatu bahan dapat diketahui melalui uji aktivitas antioksidan. Pengujian aktivitas antioksidan dalam lintah laut dilakukan dengan metode DPPH. Hasil analisis $\mathrm{IC}_{50}$ aktivitas antioksidan lintah laut (Discodoris sp.) dapat dilihat pada Gambar 1.

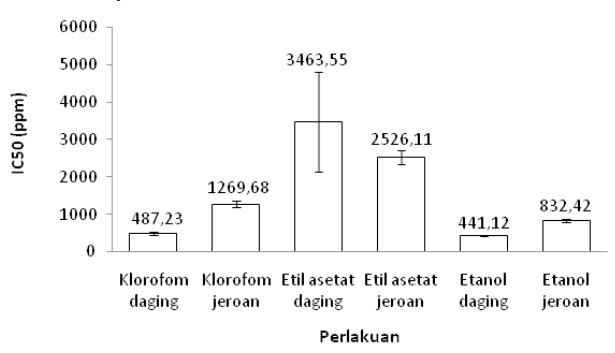

Gambar 1. Hasil analisis $\mathrm{IC}_{50}$ aktivitas antioksidan lintah laut (Discodoris sp.)

Suatu senyawa dikatakan sebagai antioksidan sangat kuat apabila nilai $\mathrm{IC}_{50}$ kurang dari $50 \mu \mathrm{g} / \mathrm{ml}$, kuat apabila nilai $\mathrm{IC}_{50}$ antara 50-100 $\mu \mathrm{g} / \mathrm{ml}$, sedang apabila nilai $\mathrm{IC}_{50}$ berkisar antara 100-150 $\mu \mathrm{g} / \mathrm{ml}$, dan lemah apabila nilai $\mathrm{IC}_{50}$ berkisar antara 150-200 $\mu \mathrm{g} / \mathrm{ml}$ (Blois 1958 diacu dalam Molyneux 2004). Ekstrak kasar lintah laut hasil ekstraksi dengan ketiga pelarut memiliki aktivitas antioksidan terbaik sebesar $441,12 \%$ dan tergolong lemah karena memiliki nilai $\mathrm{IC}_{50}$ lebih besar dari $200 \mathrm{ppm}$.

Nilai $\mathrm{IC}_{50}$ antioksidan dari ketiga pelarut juga masih lebih rendah dibandingkan dengan strandar yang digunakan yaitu BHT sebesar 397,04 ppm (Gambar 2). Lemahnya aktivitas antioksidan lintah laut ini dimungkinkan karena pada ekstrak kasar lintah laut masih banyak terdapat senyawa lainnya yang dapat mengurangi aktivitas antioksidannya. Penggunaan jenis pelarut berpengaruh terhadap senyawa bioaktif yang dihasilkan dan juga terhadap aktivitasnya (Seidel 2006).

Jenis senyawa antioksidan yang ada pada lintah laut dimungkinkan tergolong antioksidan primer yang mempunyai sistem kerja secara enzimatis sehingga analisis dengan menggunakan metode DPPH belum memberikan hasil yang optimal. Menurut Nurjanah (2010), aktivitas antioksidan ekstrak kasar lintah laut dengan metode NBT diperoleh hasil sebesar 79,56\% pada pelarut metanol.

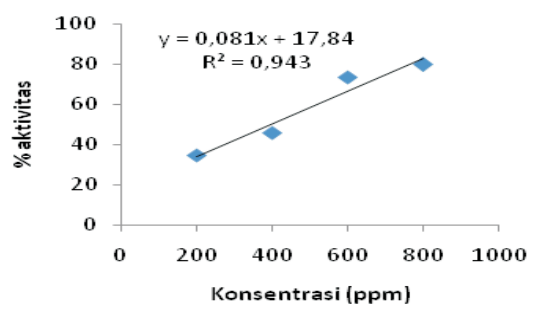

Gambar 2. Hasil analisis $\mathrm{IC}_{50}$ aktivitas antioksidan standar BHT

\section{Simpulan}

Lintah laut asal Madura berpotensi sebagai sumber protein, lemak, dan mineral. Asam amino esensial lintah laut sebesar 5,57\% yang didominasi oleh leusin sebesar 1,42\%. Asam amino nonesensial sebesar $6,54 \%$ yang didominasi didominasi oleh asam glutamat yaitu 2,19\%. Asam lemak jenuh lintah laut sebesar 27,53\% yang didominasi oleh palmitat (C16:0) yaitu 13,36\%. Asam lemak tidah jenuh sebesar $34,66 \%$ yang didominasi oleh asam lemak esensial linolenat (C18:3,n-3) 20,91\%.

Rendemen ekstrak kasar tertinggi pada ekstrak etanol dengan senyawa kimia yang terdeteksi: alkaloid, steroid, saponin, molish dan ninhidrin. Aktivitas antioksidan $\left(\mathrm{IC}_{50}\right)$ tertinggi pada daging yang diekstraksi dengan etanol yaitu 441,12 ppm.

\section{Daftar Pustaka}

American Association of Cereal Chemist [AACC]. 1983. Approved Methods of The American Association of Cereal Chemist. Ed ke-8. Maret. USA :American Association of Cereal Chemist.

American Association of Cereal Chemist [AACC] 1994. Approved Methods of The American Association of Cereal Chemist. Ed ke-9. Vol 1. USA :American Association of Cereal Chemist.

Association of Official Analytical Chemist [AOAC]. 2005. Official Methods of Analysis (18 Edn). Association of Official Analytical Chemist Inc. Mayland. USA.

Dewan Standarisasi Nasional [SNI]. 1998. Cara Uji Cemaran Logam dalam Makanan. SNI 012896-1998. Jakarta: Departemen Perindustrian RI.

Dewan Standarisasi Nasional [SNI]. 2009. Batas Maksimum Cemaran Logam Berat dalam Bahan Pangan. SNI 7387-2009. Jakarta: Badan Standarisasi Nasional. 
Departemen Kesehatan Republik Indonesia. 1995. Materia Medika Indonesia. Jakarta: Departemen Kesehatan Republik Indonesia.

Hanani E, Mun'im A, Sekarini R. 2005. Identifikasi Senyawa Antioksidan dalam Spons Callyspongia sp. dari Kepulauan Seribu. Majalah Ilmu Kefarmasian, 2(3):127 -133.

Houghton PJ, Raman A. 1998. Laboratory Handbook for the Fractionation of Natutal Extracts. London: Chapman and Hall.

Ibrahim M. 2001. Isolasi dan uji aktivitas biologi senyawa steroid dari lintah laut, Discodoris sp. [Tesis]. Program Pascasarjana. Institut Pertanian Bogor. Bogor.

Molyneux P. 2004. The use of the stable free radicals diphenylpicrylhydrazyl (DPPH) for estimating antioxidant activity. Songklanakarin J. Sci. Technol. 26(2):211219.

Naiu AS. 2011. Formulasi minuman fungsional berbahan baku lintah laut. [Tesis]. Sekolah Pascasarjana IPB. Bogor.
Nurjanah, Hardjito L, Monintja DR, Bintang M, Agungpriyono DR. 2010. Karakterisasi Lintah Laut (Discodoris sp.) sebagai antioksidan dan antikolesterol.[Disertasi]. Sekolah Pascasarjana IPB. Bogor.

Rohman A, Riyanto R, Diah U. 2006. Aktivitas antioksidan, kandungan fenolik total dan kandungan flavonoid total ekstrak etil asetat buah Mengkudu serta fraksi-fraksinya. Majalah Farmasi Indonesia. 17(3):136-142.

Seidel V. 2006. Initial and bulk ekxtraction. Methods in Biotechnology. Natural Products Isolation. Second edition. 20:27-46.

Sherif S Ebada, Ru Angelie Edrada, Wenhan Lin dan Peter Procksch. 2008. Methods for isolation, purification and structural elucidation of bioactive secondary metabolites from marine invertebrata. Nature Protocols.3(12):1820-1831. 